\title{
Conflict of laws regarding ownership of construction, agricultural and mining equipment
}

\author{
$L$ Volova $^{1,2}$ and $A$ Suzdaleva ${ }^{1,2, *}$ \\ ${ }^{1}$ Southern Federal University, Bolshaya Sadovaya str., 105/42, Rostov-on-Don, 344006, Russia, \\ ${ }^{2}$ Don State Technical University, Gagarina sqr., 1, Rostov-on-Don, 344003, Russia
}

\begin{abstract}
The purpose of this article is to analyze the features of legal regulation of property rights, enshrined in the text of the new Protocol to the Convention on International Interests in Mobile Equipment on Matters specific to mining, agricultural, and construction equipment. Methodology: In order to analyze the legal regulation of property rights enshrined in the text of the new Protocol to the Convention the provisions of the Protocol and their relationship with the provisions of the Convention (the Cape Town Convention) were examined in detail. Results: The priority of the real rights of the buyer and holders of other real rights is considered differently in the texts of Protocols. The Protocol to the Convention on mining, agricultural and construction equipment establishes an approach similar to the Protocol on Railway Transport. The means and mechanisms used to achieve this differ depending on the economic conditions prevailing in the market where the security transactions are concluded in respect of this type of equipment. Conclusions: The main purpose of the Convention and the Protocol concerning mining, agricultural, and construction equipment is to reduce the cost of credit used to purchase high-value equipment and to increase the availability of credit.
\end{abstract}

\section{Introduction}

In the context of global changes - in connection with the increase in the number of transactions with foreign participation and the intensification of international turnover of various types of property, as well as in connection with the opening of new, including hightech, production facilities on the territory of various states - attention to the legal regulation of ownership of machines is increasing and equipment. [1] This is also due to the phenomenon of digitalization of the economy and the development of international trade via the Internet, which greatly facilitates the conclusion of transactions with foreign participation and reduces the time required to conclude transactions for which the title is transferred.

These changes in public relations led to the fact that the legal regulation of ownership of machinery and equipment in the field of international trade attracted the attention of the international community. Special attention was paid to mining, agricultural and construction equipment, since these categories of equipment are of great importance for the

* Corresponding author: a.d.suzdaleva@gmail.com 
development of the relevant sectors of the economy. As a result, a new Protocol to the Convention on International Interests in Mobile Equipment on Matters specific to mining, agricultural, and construction equipment was created. [2] It was signed on November 22, 2019 , but has not yet entered into force, since it has not received the required number of ratifications. [3] The creation of this protocol is aimed at ensuring favorable conditions for the implementation of commercial activities with foreign participation in comparison with the way these legal relations are settled in the absence of international legal regulation. [4] At the same time, the Convention does not apply to security transactions related to movable property, which cannot be classified in these categories, but also often moves from one state to another. [5]

\section{Methodology}

Our goal was to resolve a research problem of a practical nature related to the establishment of the priority of property rights to mining, agricultural and construction machines that are in cross-border relations to ensure the fulfillment of obligations. This research problem is little studied in the domestic science of private international law. In order to determine possible solutions to this problem, a comparative analysis of the rules governing security transactions for certain types of equipment and enshrined in the text of the Convention on International Interests in Mobile Equipment and Protocol to the Convention on International Interests in Mobile Equipment on Matters specific to mining, agricultural, and construction equipment. The application of the generalization method allowed us to give a detailed description of the approaches enshrined in the Convention and the Protocol. Comparison of the effectiveness of these approaches in the process of legal regulation of security transactions in relation to mining, agricultural and construction machines, enshrined in the text of international legal acts, is a traditional methodology for this field of research.

\section{Results}

The legal regulation of property rights to equipment, according to the Convention, differs in each of the four existing protocols. The priority of the real rights of the buyer and holders of other real rights is considered differently, on the one hand, in the Protocols on Aircraft and Space to the Convention, and on the other hand, in the Protocol on Rail Transport. The Protocols on Air Transport and Space Facilities provide that the purchaser has an international equipment guarantee that can be registered in the International Register. However, in the Railway Protocol, only the registration of a notice of sale is possible. The Protocol to the Convention on mining, agricultural and construction machines establishes an approach similar to the Protocol on Railway Transport. The means and mechanisms used to achieve this differ depending on the type of equipment in respect of which the security interest arises, and depending on the economic conditions prevailing in the market where the security transactions are concluded in respect of this equipment.

\section{Discussion}

\subsection{Regulation of property rights in the absence of uniform rules}

In the course of the study, differences were revealed in the legal regulation of security transactions, the subject of which is, among other things, machines and equipment, in the law of different states. So, in the absence of international legal regulation of guarantees in 
relation to certain types of property (machinery and equipment), real rights that have arisen earlier in relation to this property, in the event of the transfer of property to a foreign legal order, will be governed by the conflict of laws of the internal law of each state, namely, in accordance with the law of the country where the property is located (lex rei sitae). [6] For example, the question of whether the seller is the owner of the property in respect of which the retention of title clause has been applied will be resolved in accordance with the law of that state. [7] Moreover, third parties can make claims for the same property in a foreign state (in the state where the property is located). [8] Third party claims arising later than the rights of the purchaser of the equipment in relation to this property may take precedence over the rights of the seller. [9]

The legal regulation of security transactions differs in the law of states. When establishing the priority between the proprietary rights of various participants in relations to property, the principle nemo dat quod non habet is applied (no one has the right to transfer the right to what he has no rights to). [10] Various situations of application of this principle are possible, when there are no restrictions on its application in the legal system of the state:

1) The owner of the equipment has created security in relation to this property (equipment) in favor of one person and also sold this equipment to another person. In this case, the determination of the priority of the property rights of these persons in relation to this property will depend solely on the sequence of these events. If the equipment was sold before the security transaction was concluded, then the seller has no rights to the property and therefore cannot create security in respect of that property. In this situation, the buyer's right has priority.

2) The owner of the equipment created the collateral prior to the sale of the equipment. In this case, the arisen real right follows the thing and the buyer accepts the thing in respect of which the security interest of another person is valid. The same rules apply when an asset is sold twice by the owner to two different people. The nemo dat principle is intended to ensure the inviolability of property rights.

Thus, re-disposing of property or creating a second interest is illegal. However, the priority of the rights of the purchaser of equipment is not established in all cases, since the legal systems of different countries establish various restrictions on the nemo dat principle. [11] The consolidation of the limitations of this principle is due to several reasons:

1) Applying the nemo dat principle without exception can lead to unfair results. For example, in a situation where a person has full ownership of the property, but in fact another person has a "secret" security interest in the same equipment. In this situation, the subordination of the buyer's right to this "secret" security interest would be clearly unfair. This argument is reinforced if the person holding the "secret" security interest has the ability to make the interest publicly known, but does not. In the law of a large number of states, the buyer who leaves the goods at the seller's place (the equipment is not actually handed over to him) loses to the later buyer to whom the equipment is transferred.

2) Exceptions to the nemo dat principle are intended to facilitate trading. The buyer incurs additional costs in the process of ascertaining whether the seller of the equipment actually owns the property, which is free of encumbrances. [12] When goods are sold in ordinary trade, there is a strong case for applying the nemo dat constraints. These exceptions and limitations of the nemo dat principle in the law of each state reflect the balance of interests between buyers and owners of property rights over time. [13] The law of each state reflects the state of the market for various types of machinery and equipment and the degree of difficulty in making public a security interest in respect of equipment, as well as the ease with which a subsequent buyer or acquirer of a limited property right can ascertain the existence of this interest. For example, the first purchaser can usually make the ownership of the property publicly known by taking 
delivery, while the holder of the security interest chooses not to, or cannot even do so. If the holder of a security interest participates in a security transaction, then it is likely that he will look in the register for information about the rights to this equipment, since it is possible that he himself will register his rights to this property in the register. [14] The ratio between the interest of the buyer of the equipment and the interest of the holder of the security interest in this equipment in this situation will depend on the degree of complexity of the procedure for searching for information on the rights to property in the register and on the economic conditions of interaction between the parties to the security transaction in this market. [15] For example, in the case of acquiring rights to a high-value property for which transactions are infrequent, the purchaser is likely to make the best possible effort to find out who owns the rights to that property. Conversely, for low-cost items that are frequently sold, the buyer will not make such an effort. These factors are expressed in the text of the Protocol to the Cape Town Convention and, among others, determine their difference.

This situation entails legal uncertainty for participants in international commercial turnover.

\subsection{Regulation of property rights under the Cape Town Convention}

The approach enshrined in the text of the Convention does not actually apply to such types of mobile equipment as aviation and railway transport, as well as space equipment. This approach is used in relation to mining, agricultural and construction equipment. This approach will also be applied to any other categories of equipment for which protocols to the Convention will be adopted in the future (if they do not contain special provisions).

The basic rule according to which the priority of the rights to equipment is determined is enshrined in paragraph 3 of Article 29 of the Convention. The buyer of the object acquires the rights to the equipment:

a. subject to encumbrance with any guarantee registered at the time of acquisition of these rights;

b. free from being encumbered by an unregistered guarantee, even if he actually knew about the existence of such guarantee.

Obviously, this provision is an exception to the nemo dat principle. The holder of the international guarantee, who registered it first, in the case of unlimited application of the nemo dat principle, would win. However, as a result of the application of this rule, which is an exception to the nemo dat principle, his right gains priority only if he registered his guarantee before the sale, that is, the transfer of ownership to the buyer.

If this person, by the time of the sale of the equipment, was the first to register the warranty in time, he will lose his security interest in this equipment. In this case, the purchaser of the equipment acquires the right of ownership without encumbrances. The earlier, but not duly registered, international guarantee disappears completely. The basis for securing this exception from the nemo dat principle was the creation of an international registry. The registration of an international guarantee in this registry is the only means of publicizing an earlier security interest. In this case, the subsequent security interest is limited to the earlier interest. Even if the buyer is aware of the existence of an unregistered security interest in the equipment, his interest is not limited to an earlier interest, as he is guided only by the international registry. The purpose of enforcing this provision is to avoid a situation where the buyer has to carry out costly verification of the seller's title and the presence of encumbrances of ownership of the equipment. In addition, in this case, it becomes possible to avoid complex and lengthy disputes about whether the buyer knew about the presence or absence of other security interests in the property. The application of this exception to the nemo dat principle creates a situation in which buyers of equipment 
tend to search in the international register as the only reliable source of information, which significantly increases the level of legal certainty in the regulation of security transactions in cross-border relations.

\subsection{Regulation of property rights under the Protocol to the Convention on International Interests in Mobile Equipment on Matters specific to mining, agricultural, and construction equipment}

It seems that the most effective way to resolve the problem mentioned in paragraph 4.1 is the substantive unification of the rules governing security transactions in relation to mining, agricultural and construction machines. Substantive unification was successfully carried out in connection with the adoption of the UNIDROIT Convention on International Interests in Mobile Equipment 2001. In addition to this convention, the corresponding Protocols have been created, as indicated in Table 1.

The Protocol to the Convention on International Interests in Mobile Equipment on Matters specific to mining, agricultural, and construction equipment, regulating the provisions arising in relation to mining, agricultural and construction machines, has not yet entered into force, since it has not received the required number of ratifications. However, more states are expected to accede to this Protocol, which necessitated studying the specifics of its application.

Table 1. Protocols to the Convention on International Interests in Mobile Equipment.

\begin{tabular}{|l|c|c|}
\hline \multicolumn{1}{|c|}{$\begin{array}{c}\text { Protocol to the Convention on } \\
\text { International Interests in Mobile } \\
\text { Equipment }\end{array}$} & Date of adoption & Entry into force \\
\hline $\begin{array}{l}\text { Protocol to the Convention on International } \\
\text { Interests in Mobile Equipment on matters } \\
\text { specific to aircraft equipment }\end{array}$ & 16 November 2001 & $\begin{array}{l}\text { Entered into force in } 73 \\
\text { Contracting Parties }\end{array}$ \\
\hline $\begin{array}{l}\text { Protocol to the Convention on International } \\
\text { Interests in Mobile Equipment on Matters } \\
\text { Specific to Railway Rolling Stock }\end{array}$ & 23 February 2007 & Not in force \\
\hline $\begin{array}{l}\text { Protocol to the Convention on International } \\
\text { Interests in Mobile Equipment on Matters } \\
\text { specific to Space Assets }\end{array}$ & 9 March 2012 \\
\hline $\begin{array}{l}\text { Protocol to the Convention on International } \\
\text { Interests in Mobile Equipment on Matters } \\
\text { specific to mining, agricultural, and } \\
\text { construction equipment }\end{array}$ & 22 November 2019 & Not in force \\
\hline
\end{tabular}

\subsubsection{Registering a sales notice}

The registration of notices affects the priority of interests under national law. It is not the ultimate purpose of such registration to exert any influence on the prioritization of property rights enshrined in the national law of the participating States. The main goal is different. The buyer seeks to register the notice of sale, not in order to secure the priority of his right to the equipment as such, but in order to reduce the risk of a future long and costly dispute related to a conflict of interest with another buyer or holder of an international warranty in respect of this equipment. In this case, if the subsequent acquirer of the property or the holder of the security interest (creditor) receives information about the registration of the notice of sale, he will also otherwise assess the legal risks of concluding a transaction with this seller and, possibly, refuse to conclude the transaction. In addition, even if a subsequent buyer and security interest in the equipment decides to continue doing business with that 
seller, they will have to conduct a costly study of what encumbrances exist on the property. It is also possible that in this case he would have to enter into a priority agreement with the first buyer.

Thus, there is a clear benefit to the purchaser by registering a notice of sale in the international register, as it reduces the likelihood of future disputes regarding the priority of equipment rights. In addition, such a system for registering a notice of sale is beneficial to the person investigating whether the seller is entitled to sell the equipment or to enter into a security transaction in respect of the equipment (the subsequent buyer or holder of a security interest in the equipment), because if the result is unfavorable for him investigations, this person will be able to stop doing business with this seller at an early stage without incurring significant financial losses. Note, however, that a subsequent purchaser or security interest in the equipment could otherwise have searched for this information without resorting to the help of an international registry, but the costs of such a search for information would have cost him much more. sale notifications. In addition, the economic efficiency of such a system is determined by the economic conditions prevailing in the market where the sale and purchase agreements and security transactions are concluded for the category of mobile equipment under consideration.

\subsubsection{Prioritizing rights to equipment upon sale}

The approach enshrined in the Protocol to the Convention on International Interests in Mobile Equipment on Matters specific to mining, agricultural, and construction equipment repeats the Protocol on rail transport. However, another new provision has been added for equipment held for sale by a dealer in the normal course of business. The argument in favor of consolidating this provision was that buyers of inventory from a dealer should not search the international registry to find out if the property has other registered international guarantees under which the dealer is a debtor. The effect of paragraphs 3 and 4 of Article 29 of the Convention is amended so that the buyer is exempted from any such international interests, unless the domestic law of the State provides otherwise. This provision applies only to those international interests for which the dealer is a debtor. In turn, the purchaser of the equipment, as before, will be subject to any registered international interests created by another person.

\section{Conclusions}

The purpose of the Convention and the Protocol to the Convention on International Interests in Mobile Equipment on Matters specific to mining, agricultural, and construction equipment is to reduce the cost of credit used to purchase high-value equipment and to increase the availability of credit. This goal is supposed to be achieved by ensuring an international system of rules allowing the creditor to exercise a security interest in this equipment in such a way that in the event of default by the debtor in the obligation, the interests of the creditor are adequately protected. The means of securing the creditor's rights in the secured obligation is the registration of rights to the equipment in the International Register and the possibility of verifying the existence of other existing or prior interests in the equipment. Thus, the main task of the Convention and the Protocol to the Convention on International Interests in Mobile Equipment on Matters specific to mining, agricultural, and construction equipment is primarily not to protect the property rights of buyers of equipment and creditors (sellers). However, the Convention and the Protocol to the Convention on International Interests in Mobile Equipment on Matters specific to mining, agricultural, and construction equipment should nonetheless take into account and protect the rights of buyers and sellers. The means and mechanisms used to achieve this differ 
depending on the type of equipment in respect of which the security interest arises, and depending on the economic conditions prevailing in the market where the security transactions are concluded in respect of this equipment.

\section{References}

1. B. Akkermans, C. Rupp, European Property Law Journal 7, 209-211 (2008)

2. V.B. Benjamin, H. Rosen, Revue de droit uniforme, 1-24 (2018)

3. C. Mooney, M. Dubovec, W. Brydie-Watson, Revue de droit uniforme 21, 332-360 (2016)

4. L. Gullifer, Cape Town Convention Journal 6, 97-121 (2017)

5. S.G. Roy, Law and contemporary problems 81, 135-153 (2018)

6. J. Basedow, Korea Private International Law Journal 22, 429-450 (2016)

7. M. Graziadei, Comparative Property Law: Global Perspectives (Research Handbooks in Comparative Law series) (Edward Elgar Pub., 2017)

8. L. Volova, A. Suzdaleva, International Comparative Jurisprudence 3, 179-187 (2017)

9. A. Lehavi, Vanderbilt journal of transnational law 50, 1173-1221 (2017)

10. E. Ramaekers, Oxford Journal of Legal Studies 6, 1-30 (2017)

11. S. Sztranyiczki, Acta Universitatis Sapientiae, European and Regional Studies 10, 105119 (2016)

12. E.-M. Kieninger, European Property Law Journal 7(3), 221-245 (2018)

13. H. Gabriel, Cape Town Convention Journal 4(1), 67-75 (2015)

14. R. Kayibanda, The Estey Centre Journal of International Law and Trade Policy 14(2), 68-86 (2013)

15. M. Deschamps, Cape Town Convention Journal 2(1), 51-64 (2013) 